\title{
ASAS ULTIMUM REMEDIUM TERHADAP ANAK YANG BERKONFLIK DENGAN HUKUM DALAM RANGKA PERLINDUNGAN ANAK
}

\author{
Beby Suryani Fithri \\ Universitas Medan Area \\ bebysuryani07@gmail.com
}

\begin{abstract}
A B S T R A K
Asas ultimum remedium terhadap anak yang berkonflik dengan hukum bertujuan untuk melindungi anak agar dapat menyongsong masa depannya yang masih panjang dengan menjauhkannya dari sistem peradilan pidana. Penelitian ini jenisnya penelitian yuridis normatif dan penelitian ini juga bersifat deskriptif analitis. Asas ultimum remedium secara implisit terdapat di dalam beberapa peraturan hukum internasional seperti pasal 37 convention of the right of the child, pasal 46 the riyadh guidelines, pasal 16 the tokyo rules, pasal 13 beijing rules serta keberadaan asas ini di dalam perangkat hukum nasional juga bersifat implisit yaitu pasal 66 undang-undang no 39 tahun 1999, pasal 16 undang-undang no 23 tahun 2002 serta pasal 37 keppres no 36 tahun 1990 termasuk didalam putusan mahkamah agung nomor 125/pid/a/2012/pn.gs .

Kata Kunci : Asas Ultimum Remedium, Anak yang Berkonflik dengan Hukum, Sistem Peradilan Pidana Anak
\end{abstract}

\section{ABSTRACT}

The last resort principle to the children in conflict with the law aims to protect children in order to get his future by keeping him away from the formal criminal juvenile justice system. This research study of its kind to examine the application of normative juridical and this research is descriptive analytical. The last resort principle is found implicitly in the international regulation like article 37 convention of the right of the child, article 46 of the riyadh guidelines, article 16 the tokyo rules, article 13 of beijing rules and also found implicitly in the national regulation like article 66 the regulation number 39 of 1999, article 16 the regulation number 23 of 2002, article 37 of presidential decree number 36 of 1990and also in supreme court decision number 125/pid/a/2012/pn.gs

Keyword : The Last Resort Principle, Children in Conflict with Law, Juvenile Justice System

\section{Pendahuluan}

Anak adalah tunas, potensi, dan generasi muda penerus cita-cita perjuangan bangsa, memiliki peran strategis dan mempunyai ciri dan sifat khusus yang menjamin kelangsungan eksistensi bangsa dan negara pada masa depan. ${ }^{1}$ Anak adalah bagian yang tidak terpisahkan dari keberlangsungan hidup manusia dan keberlangsungan ssebuah bangsa dan negara. Konstitusi Indonesia memperlihatkan bahwa anak memiliki peran strategis yang secara tegas dinyatakan bahwa negara menjamin hak setiap anak atas keberlangsungan hidup,

\footnotetext{
${ }^{1}$ Huruf b Bagian Consideran Undang-

Undang Nomor 23 Tahun 2002 tentang

Perlindungan Anak
}

tumbuh dan berkembang serta atas perlindungan dari kekerasan dan diskriminasi.

Pembinaan anak dan generasi muda merupakan bagian integral dari pembangunan nasional dan juga menjadi sarana guna tercapainya tujuan pembangunan nasional yaitu, masyarakat adil dan makmur serta aman dan sentosa berdasarkan Pancasila dan Undang-Undang dasar 1945 dengan wadah Negara Kesatuan Republik Indonesia dalam ketertiban pergaulan internasional yang damai, adil dan merdeka .2

2Wagiati Soetodjo, Hukum Pidana Anak, (Bandung : PT. Refika Aditama, 2008), halaman. 62 
Konsepsi perlindungan anak meliputi ruang lingkup yang luas, dalam arti bahwa perlindungan anak tidak hanya mengenai perlindungan atas jiwa dan raga si anak, tetapi mencakup pula perlindungan atas semua hak serta kepentingannya yang dapat menjamin pertumbuhan dan perkembangan yang wajar, baik secara rohani, jasmani, maupun sosialnya sehingga anak Indonesia akan berkembang menjadi orang dewasa Indonesia yang mampu dan mau berkarya untuk mencapai dan memelihara tujuan Pembangunan Nasional tersebbut diatas. ${ }^{3}$

Perlindungan anak adalah segala usaha yang dilakukan untuk menciptakan kondisi agar setiap anak dapat melaksanakan hak dan kewajibannya demi perkembangan dan pertumbuhan anak secara wajar baik fisik, mental, dan sosial. Perlindungan anak merupakan perwujudan adanya keadilan dalam suatu masyarakat, dengan demikian perlindungan anak diusahakan dalam berbagai bidang kehidupan bernegara dan bermasyarakat ${ }^{4}$

Kegiatan perlindungan anak membawa akibat hukum, baik dalam kaitannya dengan hukum tertulis maupun hukum tidak tertulis. Hukum merupakan jaminan bagi kegiatan perlindungan anak. Arif Gostita mengemukakan bahwa kepastian hukum perlu diusahakan demi kelangsungan kegiatan perlindungan anak dan mencegah penyelewengan yang membawa akibat negatif yang tidak diinginkan dalam pelaksanaan perlindungan anak. $^{5}$

Anak-anak tidak terbebas dari kemungkinan melakukan perbuatan pidana (kejahatan) sama halnya seperti orang dewasa baik perbuatan pidana itu dilakukan sendiri maupun bersama-sama dengan orang lain. Anak yang dalam proses perkembangan mendapatkan hambatan pemenuhan kebutuhan dan perhatian menyebabkan anak terhambat perkembangannya dan bahkan dapat

\footnotetext{
${ }^{3}$ Ibid

${ }^{4}$ Maidin Gultom, Perlindungan Hukum Terhadap Anak Dalam Sistem Peradilan Pidana Anak di Indonesia, (Bandung : Pt Refika Aditama, 2008), halaman.3$$
{ }^{5} \text { Ibid }
$$

menyebabkan terganggu mentalnya. Akhirnya dapat menyebabkan anak menjadi pelaku delinquency. ${ }^{6}$ Delinkuensi menurut Ramli Atmasasmita adalah suatu tindakan atau perbuatan yang dilakukan oleh seorang anak yang dianggap bertentangan dengan ketentuan-ketentuan hukum yang berlaku di suatu negara dan yang oleh masyarakat itu sendiri dirasakan serta ditafsirkan sebagai perbuatan yang tercela. ${ }^{7}$

Penanggulangan tindak pidana yang dilakukan oleh anak perlu mempertimbangkan kedudukan anak dengan segala ciri dan sifatnya yang khas, walaupun anak telah dapat menentukan sendiri langkah perbuatannya berdasarkan perasaan, pikiran, dan kehendaknya, tetapi keadaan sekitarnya dapat memengaruhi perilakunya. Orang tua dan masyarakat sekelilingnya lebih bertanggung jawab terhadap pembinaan, pendidikan, dan pengembangan perilaku anak dalam hal menghadapi masalah anak nakal. ${ }^{8}$

Mengenai batasan umu anak yang berkonflik dengan hukum yakni orang yang telah mencapai umu 8 tahun tetapi belum mencapai umur 18 tahun dan belum pernah kawin. Batasan umur anak yang berkonflik dengan hukum kemudian naik menjadi 12 tahun. Perubahan ini dilakukan oleh Mahkamah Konstitusi melalui putusannya Nomor 1/PUU/VIII/2010 sehubungan dengan diajukannya judicial review terhadap undang-undang pengadilan anak oleh komisi perlindungan anak Indonesia.

Penjatuhan pidana secara tidak tepat dapat mengabaikan pengaturan perlindungan, karena pemidanaan anak seharusnya adalah jalan keluar terakhir dan dijatuhkannya hanya untuk waktu yang singkat. Penjatuhan pidana sebagai ultimum remedium adalah salah satu bentuk perlindungan terhadap kepentingan terbaik anak.

Prof Mr. J.C Hudig, guru besar hukum pidana anak di Universitas Negeri

\footnotetext{
${ }^{6}$ Marlina (1), Peradilan Pidana Anak di Indonesia Pengembangan Konsep Diversi dan Restorative Justice, (Bandung : PT Refika Aditama, 2009), halaman.60

${ }^{7}$ Maidin Gultom, Ibid, halaman.55

${ }^{8}$ Penjelasan Undang-Undang Nomor 3 Tahun 1997 Tentang Pengadilan Anak
} 
Utrecht menyatakan tentang tindakan terbaik apa yang harus ditempuh untuk menyelesaikan perkara anak sebagai berikut :?

'Pada umunya dapat saya kemukakan bahwa suatu penuntutan pidana itu dilakukan apabila kesulitan dari pembuat muda itu jelas berpusat pada tindak pidana yang dilakukan. Akan tetapi apabila tindak pidana itu merupakan gejala dari suatu keadaan yang tidak dikehendaki (tidak baik), suatu hal yang berkebetulan, salah satu dari sekian banyak bentuk perbuatan yang jelek, yang bersumber pada keadaan keluarga, maka hasilnya akan lebih baik apabila ditempuh jalan pemberian tindakan secara hukum perdata berupa penyerahan kepada negara untuk dibina.'

Filosofi sistem peradilan pidana anak yaitu mengutamakan perlindungan dan rehabilitasi terhadap pelaku anak sebagai orang yang masih mempunyai sejumlah keterbatasan dibandingkan dengan orang dewasa. Anak memerlukan perlindungan dari negara dan masyarakat dalam jangka waktu ke depan yang masih panjang. Terhadap anak yang terlanjur menjadi pelaku tindak pidana diperlukan strategi sistem peradilan pidana yaitu mengupayakan seminimal mungkin intervensi sistem peradilan pidana. ${ }^{10}$

Perlindungan terhadap anak salah satunya dilakukan dengan menjauhkan proses formal sistem peradilan pidana anak itu sendiri. Timbul pemikiran manusia atau para ahli hukum dan kemanusiaan untuk membuat aturan formal tindakan mengeluarkan seorang anak yang melakukan pelanggaran hukum atau tindak pidana dari proses peradilan pidana dengan memberikan alternatif lain yang dianggap lebih baik untuk anak yang kemudian melahirkan konsep diversi. ${ }^{11}$

${ }^{9}$ Sudarto, Kapita Selekta Hukum Pidana, (Bandung : Alumni, 2006), halaman 142-143

${ }^{10}$ Marlina (2), Pengantar Konsep diversi dan Restorative Justice Dalam Hukum Pidana, 9Medan ; USU Press, 2010), halaman.1

${ }^{11}$ Ibid
Konsep diversi didasarkan pada kenyataan bahwa proses peradilan pidana terhadap anak pelaku tindak pidana melalui sistem peradilan pidana lebih banyak menimbulkan bahaya daripada kebaikan. Alasan dasarnya yaitu pengadilan akan memberikan stigmatisasi terhadap anak atas tindakan yang dilakukannya seperti anak dianggap jahat, sehingga lebih baik untuk menghindarkannya ke luar sistem peradilan pidana. ${ }^{12}$

Perlindungan terhadap anak melalui pemberlakuan asas ultimum remedium telah dilakukan tidak hanya di dalam perangkat aturan internasional tetapi juga di dalam perangkat hukum nasional dan di dalam putusan pengadilan yang mengadili tentang anak

Putusan Mahkamah Agung Republik Indonesia terhadap WHD, remaja laki-laki usia 15 tahun yang terjerat kasus pencurian dalam keadaan memberatkan merupakan bentuk penegakan hukum pidana terhadap anak yang berkonflik dengan hukum yang mnyentuh sisi kemanusiaan masyarakat luas sehubungan dengan motif pelaku untuk memperoleh uang jajan dari tindak pidana yang dilakukannya. Dalam Putusan Mahkamah Agung Nomor 125/pid/a/2012/pn.gs, WHD kemudian dijatuhkan hukuman tindakan dengan mengembalikannya kepada orang tua setelah sebelumnya melalui proses peradilan pidana yang panjang yang seharusnya bisa diselesaikan lewat jalur alternatif lain sehubungan dengan jiwa peradilan anak yang menghendaki sistem peradilan pidana anak sebagai upaya akhir.

Berdasarkan uraian tersebut diatas, kemudian dilakukanlah penelitian untuk mengkaji lebih dalam mengenai asas ultimum remedium terhadap anak yang berkonflik dengan hukum.

\section{Rumusan Masalah}

Yang menjadi Rumusan Masalah Pada penelitian ini adalah :

1. Bagaimana adopsi/keberadaan asas ultimum remedium di dalam instrumen hukum internasional yang mengatur tentang anak yang berkonflik dengan hukum?

${ }^{12}$ Ibid halaman 11 
2. Bagaimana adopsi/keberadaan asas ultimum remedium di dalam instrumen hukum nasional yang mengatur tentang anak yang berkonflik dengan hukum?

3. Bagaimana adopsi/keberadaan asas ultimum remedium terhadap anak yang berkonflik dengan hukum dalam Putusan Mahkamah Agung RI No.125/Pid/A/2012/PN.GS?

\section{Metode Penelitian}

Menurut Soerjono Soekanto bahwa $: 13$

Metode adalah proses, prinsipprinsip dan tata cara memecahkan suatu masalah sedangkan penelitian adalah pemeriksaan secara hati-hati, tekun dan tuntas terhadap suatu gejala untuk menambah pengetahuan manusia, maka metode penelitian dapat diartikan sebagai proses prinsip-prinsip dan tata cara untuk memecahkan masalah yang dihadapi dalam melakukan penelitian.

"Penelitian adalah kegiatan ilmiah yang didasarkan pada metode pencarian asas sesuatu (inquiry) secara sistematis dengan adanya penekanan bahwa pencarian ini dimana dilakukan terhadap suatu masalah-masalah yang dapat dipecahkan. ${ }^{14}$ Yang bertujuan untuk mempelajari satu atau beberapa gejala hukum tertentu dengan jalan menganalisanya". ${ }^{15}$

Sedangkan menurut Sutrisno Hadi "penelitian atau research adalah usaha untuk menemukan, mengembangkan dan menguji kebenaran suatu pengetahuan usaha mana dilakukan dengan metodemetode ilmiah". ${ }^{16}$

Salah satunya adalah melalui kegiatan ilmiah, seperti penelitian dimana dalam penelitian tersebut akan mencari data atau bahan-bahan yang dapat dipergunakan untuk penulisan ilmiah.

13Soerjono Soekanto, Penelitian Hukum Normatif suatu tinjauan singkat, (Jakarta : Raja Grafindo Persada, 1995) , halaman 6.

${ }^{14}$ Moh. Nazir, Metode Penelitian, (Jakarta

: Ghalia Indonesia, 1998), halaman 13.

${ }^{15}$ Soerjono Soekanto, Ibid, halaman 43.

16Sutrisno Hadi, Metode Research Jilid I, (Yogyakarta : Penerbit Andi, 2000), halaman 4.
Dimana data adalah merupakan gejala yang akan dicari untuk diteliti, gejala yang diamati oleh peneliti dan hasil pencatatan terhadap gejala yang diamati oleh peneliti". 17

\section{A. Jenis dan sifat penelitian}

Penelitian ini jenisnya Penelitian Yuridis Normatif. Pendekatan Yuridis Normatif, yakni penelitian yang difokuskan untuk mengkaji penerapan atau kaidahkaidah atau norma-norma dalam hukum positif. ${ }^{18}$ Bentuk dari hasil penelitian ini akan dituangkan secara deskriptif. Suatu penelitian deskriptif, dimaksudkan untuk memberikan gambaran yang seteliti mungkin manusia, keadaan atau gejalagejala lainny, ${ }^{19}$ yang dalam hal ini dibatasi mengenai asas ultimum remedium di dalam sistem peradilan pidana anak

Penelitian bersifat deskriptif analitis yaitu merupakan penelitian yang bertujuan menggambarkan secara cermat karakteristik dari fakta-fakta (individu, kelompok atau keadaan) dan untuk menentukan frekuensi sesuatu terjadi. ${ }^{20}$ Analisis yang dimaksudkan berdasarkan gambaran, fakta yang diperoleh akan dilakukan analisis secara cermat untuk menjawab penelitian. ${ }^{21}$

Penelitian yang digunakan dalam penelitian ini bersifat metode berpikir deduktif ke induktif yang menggambarkan dan menguraikan tentang asas ultimum remedium terhadap anak yang berkonflik dengan hukum.

\section{B. Sumber Data}

Dalam penelitian ini diperoleh melalui data sekunder yaitu data yang

\footnotetext{
${ }^{17}$ Soerjono Soekanto dan Sri Mamudji, Peran Penggunaan Perpustakaan di dalam penelitian Hukum, (Jakarta : PDHUI, 1979), halaman 1.

18Johnny Ibrahim, teori dan metodologi penelitian hukum normatif, (Malang : Banyumedia publishing, 2008), halaman 295.

${ }^{19}$ Soerjono Soekanto, pengantar penelitian hukum, (Jakarta : UI press, 2006), halaman 10 .

${ }^{20}$ Rianto Adi, Metode Penelitian Sosial dan Hukum, (Jakarta : Granit, 2000), halaman 58.

${ }^{21}$ Sunaryati Hartono, Penelitian Hukum Indonesia pada Akhir ke-20, (Bandung : Alumni, 1994), halaman 101.
} 
dikumpulkan melalui studi dokumen terhadap bahan kepustakaan. Di dalam penelitian hukum, data sekunder terdiri dari:

1. Bahan hukum primer

Bersumber dari bahan hukum yang diperoleh langsung dan akan digunakan dalam penelitian ini yang merupakan bahan hukum yang mempunyai kekuatan mengikat secara yuridis, yaitu :

1. Norma atau kaidah dasar yaitu, Alinea keempat Pembukaan UndangUndang Dasar Negara Republik Indonesia Tahun 1945

2. Peraturan Dasar yaitu, Pasal 20, Pasal 20 A Ayat (1), Pasal 21, Pasal 28 B Ayat (2) dan Pasal 34 UndangUndang Dasar Negara Republik Indonesia Tahun 1945

3. Undang-Undang yang terkait dengan asas ultimum remedium terhadap anak yang berkonflik dengan hukum, seperti UU no.3 Tahun 1997 Tentang Pengadilan Anak, UU No. 23 Tahun 2002 Tentang Perlindungan Anak, UU No. 39 Tahun 1999 Tentang Hak Asasi Manusia, UU No. 11 Tahun 2012 Tentang Sistem Peradilan Pidana Anak, Keputusan Presiden Nomor 36 tahun 1990 Tentang Pengesahan Konvensi tentang hakhak anak.

2. Bahan hukum sekunder

Yang merupakan bahan hukum yang erat hubungannya dengan bahan hukum primer dan dapat membantu menganalisis serta memahami bahan-bahan hukum primer, yang terdiri dari :

1. Buku-buku literatur

2. Putusan-putusan pengadilan negeri dan mahkamah agung

3. Jurnal-jurnal hukum yang berkaitan dengan asas ultimum remedium terhadap anak yang berkonflik dengan hukum

4. Makalah-makalah/laporan penelitian

5. Artikel-artikel, media massa dan internet.

3. Bahan hukum tersier

Bahan hukum yang memberikan petunjuk atau penjelasan bermakna terhadap bahan hukum primer dan sekunder, seperti kamus, ensiklopedia dan lain-lain.

\section{Metode pengumpulan data}

Pengumpulan data merupakan hal yang sangat erat hubungannya dengan sumber data, karena melalui pengumpulan data ini akan diperoleh data yang diperlukan untuk selanjutnya dianalisis sesuai dengan yang diharapkan. Metode Pengumpulan data ada 2 (dua) yaitu metode studi pustaka (library research) dan metode studi lapangan (field research). Teknik pengumpulan data dalam penelitian ini, diperoleh dari studi pustaka (library research), peraturan perundang-undangan, catatan hukum, putusan hakim, dikumpulkan dan dikaji guna menentukan relevansinya dengan kebutuhan dan rumusan masalah.

\section{Analisis Data}

Analisis data yang digunakan dalam penelitian ini yaitu analisa data kualitatif, dimana data yang terkumpul tidak berupa angka-angka yang dapat dilakukan pengukuran. Akan tetapi berdasarkan peraturan perundang-undangan, serta pandangan informasi untuk menjawab permasalahan tesis ini.

Analisis kualitatif menghasilkan data deskriptif, dengan cara penarikan data dari induktif ke deduktif dalam arti apa yang dinyatakan oleh sasaran penelitian yang bersangkutan secara tertulis, lisan dan perilaku nyata.

\section{HASIL DAN PEMBAHASAN}

\section{A. Asas Ultimum Remedium di dalam Instrumen Internasional yang Mengatur tentang Anak}

Instrumen internasional merupakan suatu produk hukum tertulis dalam perangkat ketentuan ketentuan yang dihasilkan baik oleh organisasi-organisasi internasional maupun beberapa negara berupa perjanjian, konvensi, persetujuan, protokol, piagam, kovenan, akta, deklarasi, dan instrumen internasional lainnya. Tidak ada ketentuan baik dalam hukum nasional maupun hukum internasional yang mewajibkan negara untuk meratifikasi suatu konvensi atau perjanjian internasional. PBB melalui majelis umum 
seringkali hanya menghimbau terhadap kepada negara anggotanya untuk melakukan ratifikasi terhadap suatu konvensi maupun perjanjian internasional. ${ }^{22}$

Masuknya hukum internasional ke dalam hukum nasional dan menjadi bagian dari hukum nasional serta dalam beberapa hal memberi warna terhadap hukum nasional, menunjukkan bahwa negaranegara tidak bisa mengabaikan arti dan peranan dari hukum internasional. Sejauh mana suatu negara sudah peka dan tanggap terhadap perkembangan hukum internasional dapat diketahui dari pengaturan suatu masalah di dalam undangundang nasionalnya, di mana masalah itu sendiri juga sudah diatur secara canggih dan aktual di dalam sebuah konvensi internasional. ${ }^{23}$

Perangkat hukum internasional dibutuhkan oleh hukum nasional, sebab hukum internasional dapat menjadi masukan bagi hukum nasional berkenaan dengan suatu masalah yang pengaturannya terlebih dahulu muncul di dalam hukum internasional. Sebagai bahan masukan suatu negara itu bisa melakukannya dengan jalan meratifikasi konvensi yang mengatur masalah tentang maslah tersebut atau kalau negara itu tidak ingin meratifikasi dapat menempuh dengan jalan mengadaptasi isi dan jiwa konvensi tersebut untuk selanjutnya diatur di dalam undang-undang nasionalnya. ${ }^{24}$

Perlindungan terhadap anak merupakan tanggung jawab yang diemban oleh masyarakat termasuk jika anak tersebut melakukan tindak pidana. Pembinaan terhadap anak yang berkonflik dengan hukum merupakan kewajiban bagi warga masyarakat sebagaimana telah ditentukan oleh hukum internasional yang berlaku. Beberapa instrumen hukum internasional yang mengatur tentang anak yang berkonflik dengan hukumterkait asas ultimum remedium yakni

\footnotetext{
${ }^{22}$ Sumaryo asuryokusumo, Studi Kasus Hukum Internasional, (Jakarta : tatanusa, 2007), halaman 178

${ }^{23}$ I Wayan Parthiana, Pengantar Hukum Internasional, (Bandung : Mandar Maju, 2003), halaman 328$$
{ }^{24} \text { Ibid }
$$

\section{Convention of the right of the child}

Perkembangan yang sangat berarti bagi perhatian masyarakat internasional mengenai hak-hak anak dan sekaligus merupakan tindak lanjut pencanangan deklarasi hak-hak anak yaitu dengan disahkannya Resolusi PBB 44/25Convention of the right of the child atau Konvensi hak-hak anak. Perlindungan hukum terhadap anak yang berkonflik dengan hukum dalam konvensi ini dapat dilihat sebagai berikut

Article 37(pasal 37)

States parties shall ensure that (Pihak Negara Menjamin bahwa) :

a. No child shall be subjected to torture or other cruel, inhuman or degrading treatment or punishment. Neither capital punishment nor life imprisonment without possibility of release shall be imposed for offences committed by person below eighteen years of age ( tidak ada anak yang akan dikenakan penyiksaan atau kekejaman lainnya, ketidakmanusiawian atau penghinaan atau hukuman baik itu hukuman negara ataupun penjara seumur hidup tanpa kemungkinan bebas tidak akan dijatuhkan bagi pelanggaran yang dilakukan oleh mereka yang berada dibawah usia 18 tahun )

b. No child shall be deprived of his or her liberty unlawfully or arbitrarily. The arrest, detention or imprisonment of a child shall be in confirmity with the law and shall be used only as a measure of last resort and for the shorthest appropriate period of time ( tidak ada anak yang akan dihilangkan kebebasannya secara tidak sah atau sewenang-wenang. Penangkapan, penahanan atau memenjarakan seorang anak akan disesuaikan dengan hukum dan hanya akan digunakan sebagai upaya terakhir untuk jangka waktu yang singkat )

c. Every child deprived of liberty shall be treated with humanity and respect for the inherent dignity of the human person, and in a manner which takes into account the needs of persons of his or her age. In particular, every child deprived of liberty shall be separated 
from adults unless it is considered in the child's best interest not to do so and shall have the right to maintain contact with his or her family through correspondence and visits, save in exceptional- circumtances ( setiap anak yang dirampas kebebasannya harus diperlakukan manusiawi dan menghormati martabat manusia yang melekat, dan dalam suatu cara dan mengingat akan kebutuhan-kebutuhan orang pada umumnya. Terutama setiap anak yang dirampas kebebasannya harus dipisahkan dari orang dewasa kecuali penempatannya itu dianggap demi kepentingan si anak dan harus mempunyai hak untuk mempertahankan hubungan dengan keluarga melalui surat menyurat dan kunjungan, kecuali bila dalam keadaankeadaan luar biasa )

d. Every child deprived of his or her liberty shall have the right to prompt access to legal and other appropriate assistance, as well as the right to challenge the legality of the deprivation of his or her liberty before a court or other competent, independent and impartial authority, and to a prompt decision on any such action ( setiap anak yang dirampas kebebasannya berhak atas akses segera ke bantuan hukum dan bantuan lain yang tepat, dan juga hak untuk menyangkal keabsahan perampasan kebebasannya di hadapan suatu pengadilan atau penguasa lain yang berwenang, mandiri, dan adil, dan atas putusan segera mengenai tindakan apa pun semacam itu)

Pokok convention of the right of the child khususnya pasal 37 dalam rangka memberikan perlindungan bagi anak yang berkonflik dengan hukum yakni, pertama konvensi ini menghendaki penyeragaman usia anak yang mendapatkan perlindungan khusus yaitu dibawah 18 tahun. Kedua, perlindungan terhadap anak yang berkonflik dengan hukum dilakukan dengan cara menjauhkannya dari sistem peradilan pidana anak dengan menjadikan hal tersebut sebagai jalan terakhir dan apabila permasalahan anak harus diselesaikan lewat penjatuhan hukuman maka pemenjaraan seumur hidup dihapuskan baginya serta ia harus mendapat bantuan hukum dan fasilitas yang memadai

\section{The riyadh guidelines}

The riyadh guidelines merupakan suatu pedoman pencegahan kenakalan anak yang terdiri dari 66 pasal. Riyadh guidelines ditetapkan melalui resolusi PBB nomor 45/112 dalam sidang pleno PBB ke 68 tahun 1990. Bagian lampiran riyadh guidelines menyebutkan bahwa pencegahan tindak pidana anak merupakan bagian utama pencegahan kejahatan di dalam masyarakat. Pencegahan tersebut dilakukan melalui pendayagunaan sarana perundangundangan, aktivitas sosial yang bermanfaat, melakukan pendekatan manusiawi terhadap segala aspek kehidupan kemasyarakatan serta memperhatikan kehidupan anak, sehingga melalui hal ini anak-anak dapat mengembangkan sikap-sikap non criminogen.

Anak yang berkonflik dengan hukum juga mendapat perhatian di dalam riyadh guidelines khususnya pada pasal 46 yakni sebagai berikut

'the institutionalization of young persons should be a measure of last resort and for the minimum necessary period, and the best interest of the young person should be a paramount importance ( pelembagaan terhadap remaja harus menjadi pilihan terakhir untuk jangka waktu yang singkat yang diperlukan, dan kepentingan terbaik bagi anak harus menjadi pertimbangan utama ).

Pasal 46 tersebut di atas merupakan kebijakan yang harus ditempuh oleh masing-masing negara untuk menempatkan anak yang berkonfik dengan hukum ke dalam lembaga pemasyarakatan sebagai jalan terakhir dan pelaksanaannya juga harus dalam jangka waktu yang singkat.

\section{The tokyo rules}

Tokyo rules merupakan resolusi PBB nomor 45/113 yang berisi 23 pasal yang mengatur tentang tindakan non penahanan yang harus dikenakan terhadap pelaku tindak pidana yang diajukan ke dalam sistem peradilan pidana. Tokyo rules lahir berdasarkan pertimbanagn untuk mengurangi penggunaan penjara terhadap 
pelaku tindak pidana dan bertujuan untuk merehabilitasi pelaku serta mengintegrasikannya kembali ke dalam masyarakat. Tokyo rules dimaksudkan untuk meningkatkan keterlibatan/peran serta masyarakat yang lebih besar khususnya dalam pembinaan pelaku tindak pidana dan meningkatkan rasa tanggung jawab pelaku tindak pida terhadap masyarakat.

Penahanan sebagai upaya akhir juga diatur dalam pasal 16 sebagai berikut

' pre trial detention shall be used as a means of last resort in criminal proceedings, with due regard for the investigation of the alleged offence and for the protection of society and the victim ( penahanan terakhir dhanan sebelum persidangan harus digunakan sebagai sarana terakhir dalam proses pidana dengan memerhatikan penyelidikan dugaan pelanggaran dan untuk perlindungan masyarakat dan korban )

Penahanan sebagai langkah terakhir yang harus dilakukan berdasarkan aturan di atas maksudnya adalah untuk mengurangi pembatasan kemerdekaan yang akan dikenakan terhadap pelaku tindak pidana, hal tersebut untuk memberikan kesempatan kepada pelaku tindak pidana untuk dapat bertanggungjawab langsung kepada masyarakat yang dirugikan akibat pelanggaran yang dilakukannya.

\section{Havana rules}

Havana rules merupakan resolusi PBB nomor 45/113 yang dihasilkan melalui sidang pleno PBB ke 68 tahun 1990 yang berisikan 87 pasal yang mengatur tentang perlindungan terhadap anak yang dirampas kemerdekaannya. Havana rules mencakup pengaturan tentang hak anak/remaja yang berada di dalam tahanan termasuk kesehatan, rekreasi, agama, mendapatkan fasilitas yang memadai, pendidikan, pelatihan kerja, dsb.

$$
\text { Havana rules menyatakan }
$$

pemenjaraan sebagai upaya akhir dalam menyelesaikan permasalahan anak yang berkonflik dengan hukum. Pengaturan asas ultimum remedium dalam havana rules terbatas pada pemenjaraan anak/remaja saja, berbeda dengan pengaturan yang ada di dalam convention of the right of the child yang menjadikan seluruh sistem peradilan pidana anak mulai dari penangkapan, penahanan dan pemenjaraan sebagai jalan terakhir bagi anak yang berkonflik dengan hukum. Hal ini dinyatakan dalam pandangan dasar (fundamental perspectives) sebagai berikut, ' juveniles should only be deprived of their liberty in accordance with the principles and procedures seth forth in these rules and the united nations standard minimum rules for the administration of juveniles justice. Deprivation of the liberty of a juvenile should be a disposition of last resort and for the minimum necessary period and should be limited to exectional cases. The length of the sanction should be determined by the judicial authority, without precluding the possibility of his or her early release. ( anak hanya boleh dirampas kemerdekaannya sesuai dengan prinsip dan prosedur yang ditetapkan dalam peraturan ini. Perampasan kemerdekaan anak haruslah merupakan penempatan terakhir dan untuk jangka waktu singkat yang diperlukan dan harus dibatasi untuk kasus yang luar biasa. Lamanya hukuman harus ditentukan oleh kekuasaan kehakiman tanpa menutup kemungkinan untuk melepaskannya).

\section{Beijing rules}

Beijing rules sangat dikenal di kalangan aktivispembela hak-hak anak karena untuk pertama kalinya secara detail masyarakat internasional memiliki ketentuan minimal bagaimana memperlakukan anak-anak yang berkonflik dengan hukum. Resolusi ini secara tegas mengakui bahwa anak karena tahapan awal perkembangan manusianya, memerlukan bantuan dan perawatan khusus berkenaan dengan perkembangan fisik, mental, dan sosialnya serta memerlukan perlindungan hukum mengenai kondisi damai, kemerdekaan, martabat, dan keamanannya. ${ }^{25}$

${ }^{25}$ Hadi Supeno, Kriminalisasi Anak Tawaran Gagasan Radikal Peradilan Anak Tanpa Pemidanaan, (Jakarta : PT Gramedia, 2010), halaman 82 
Asas ultimum remedium di dalam beijing rules terdapat pada pasal 13 yang menyatakan sebagai berikut

' the placement of a juvenile is an institution shall aways be a disposition of last resort and for the minimum necessary period. (penahanan sebelum pengadilan terhadap anak nakal harus dilakukan sebagai upaya akhir untuk jangka waktu singkat yang dibutuhkan)

Pasal 13 beijing rules mendorong untuk dilakukannya langkah-langkah baru dan inovatif untuk menghindari penahanan terhadap anak yang berkonflik dengan hukum.

\section{B. Asas Ultimum Remedium di dalam Instrumen Hukum nasional yang Mengatur Tentang Anak}

Asas hukum adalah prinsip-prinsip hukum yang abstrak dan pada umumnya melatarbelakangi peraturan konkret dan pelaksanaan hukum. Peraturan konkret seperti undang-undang tidak boleh bertentangan dengan asas hukum, demikian pula dalam putusan hakim, pelaksanaan hukum, dan sistem hukum. Apabila dalam sistem hukum terjadi pertentangan, maka asas hukum akan tampil untuk mengatasi pertentangan tersebut. Misalnya, terjadi pertentangan antara satu undang-undang dengan undang-undang lainyya, maka harus kembali melihat asas hukum sebaagai prinsip dasar yang mendasari suaatu peraturan hukum berlaku secara universal. ${ }^{26}$

Asas hukum senantiasa berkaitan dengan kaidah hukum atau peraturan hukum tertulis. Asas hukum merupakan landasan dan jantung dari peraturan konkret sebagai dasar-dasar pemikiran abstrak, dan didalamnya terkandung nilainilai etis yang harus diwujudkan dalam peraturan tertulis. Perbedaan antara asas hukum dengan kaidah hukum yakni : ${ }^{27}$

1. Asas hukum merupakan dasar pemikiran yang umum dan abstrak,

\footnotetext{
${ }^{26}$ Marwan Mas, Pengantar Ilmu Hukum,

(Jakarta : Ghalia, 2004), halaman 95

${ }^{27}$ Ibid halaman 99
}

sedangkan kaidah hukum merupakan aturan konkret dan riil

2. Asas hukum adalah suatu konsep atau ide yang mengandung nilai-nilai etis, sedangkan kaidah hukum adalah penjabaran dari ide tersebut yang diharapkan juga mengandung nilai-nilai etis

3. Asas hukum tidak mempunyai sanksi, sedangkan kaidah hukum mempunyai sanksi

Keberadaan asas hukum dalam sistem hukum merupakan ketentuan prinsip dalam menyelesaikan konflik dalam sistem hukum itu sendiri. Termasuk dalam melakukan rekayasa sosial, asas hukum dapat dijadikan dasar sebagaimana fungsinya untuk mewujudkan pembangunan hukum nasional yang dinamis dankondusif. Menjaga ketaatan terhadap asas hukum, akan membuat sistem hukum dan sistem peradilannya bekerja sesuai dengan fungsinya masing-masing.

Hukum pidana baik dalam pengertian ius poenale yang memuat larangan terhadap perbuatan yang bertentangan dengan hukum dan mengenakan suatu penderitaan kepada yang melanggar larangan tersebut, maupun sebagai ius poenandi, yang merefleksikan hak negara atau alat-alat perlengkapan negara untuk mengancam dan mengenakan pidana terhadap perbuatan tertentu, merupakan hukum yang sanksinya lebih berat dibandingkan sanksi bidang hukum lain seperti hukum perdata dan hukum administrasi. $^{28}$

Fungsi hukum pidana adalah untuk melindungi kepentingan hukum terhadap perbuatan yang hendak memerkosanya dengan sanksi berupa pidana yang sifatnya lebih tajam jika dibandingkan dengan sanksi yang terdapat pada cabang ilmu hukum lainnya. Sanksi pidana itu di dalamnya terdapat suatu yang menyedihkan sehingga hukum pidana dikatakan mengiris dagingnya sendiri atau sebagai pedang bermata dua. Hal tersebut bermakna bahwa hukum pidana bertujuan untuk melindungi

${ }^{28}$ Muladi, Makalah Ambiguitas dalam Penerapan Doktrin Hukum Pidana Antara Doktrin Ultimum remedium dan Doktrin Primum Remedium, Makassar, 2003, halaman 1 
kepentingan-kepentingan hukum (misalnya nyawa, harta benda, kemerdekaan, kehormatan J namun, jika terjadi pelanggaran terhadap larangan dan perintahnya justru menyakiti kepentingan hukum si pelanggar. Perlu diingat pula, bahwa sebagai alat social control, fungsi hukum pidana adalah subsidair, artinya hukum pidana hendaknya baru diadakan/dipergunakan apabila usahausaha lain kurang memadai. ${ }^{29}$

Van Bemmelen menyatakan bahwa yang membedakan antara hukum pidana dan bidang hukum lain, ialah sanksi hukum pidana merupakan pemberian ancaman penderitaan dengan sengaja dan sering juga pengenaan penderitaan, hal mana dilakukan juga sekalipun tidak ada korban kejahatan. Perbedaan demikian menjadi alasan untuk menganggap hukum pidana itu sebagai ultimum remedium, yaitu upaya terakhir guna memperbaiki tingkah laku manusia terutama penjahat serta memberikan tekanan psikologis agar orang lain tidak melakukan kejahatan. $^{30}$ Hukum pidana adalah alat pertahanan sosial terakhir yang baru dapat digunakan ketika bidang hukum lain tidak mampu mengendalikan suatu perbuatan, yang dimanifestasikan dalam tataran kebijakan fungsionalisasi hukum pidana melalui peraturan perundangundangan. Ultimum remedium tidak hanya berarti berhemat dalam menegakkan hukum pidana. Jadi, hukum pidana bersifat ultimum remedium, bukan hanya dalam tataran formulasi ( yaitu ketika memutuskan untuk menetapkan suatu perbuatan sebagai tindak pidana), tetapi juga dalam tataran aplikasi (yaitu ketika menerapkan hukum pidana terhadap peristiwa konkrit).

Sanksi pidana harus disepadankan dengan kebutuhan untuk melindungi dan mempertahankan kepentingan-kepentingan sosial. Pidana hanya dibenarkan apabila ada kebutuhan yang berguna bagi masyarakat. Pidana yang yang tidak diperlukan, tidak dapat dibenarkan dan berbahaya bagi

${ }^{29}$ Mohammad Ekaputra, Dasar-Dasar

Hukum Pidana, (Medan : USU Press, 2010), halaman 13

${ }^{30}$ Zainal Abidin farid, Hukum Pidana I, (Jakarta : Sinar Grafika, 2007), halaman 13 masyarakat. Selain itu, batas-batas sanksi pidana ditetapkan pula berdasarkan kepentingan sosial dan nilai yang mewujudkannya.

Atas dasar pemikiran diatas, timbul pemikiran agar hukum pidana digunakan secara hati-hati dan dioperasionalkannya sebagai obat yang terakhir dan bukan sebagai obat yang utama. Doktrin ultimum remedium berarti bahwa penggunaan hukum pidana hanya dapat dilakukan apabila instrumen hukum lain seperti hukum administrasi atau hukum perdata tidak efektif. Perkataan ultimum remedium untuk pertama kali dipergunakan oleh Menteri kehakiman belanda yaitu $\mathrm{Mr}$. Modderman di depan parlemen negeri Belanda untuk menjawab pertanyaan salah seorang anggota parlemen yaitu Mr. Mckay, yang mengatakan bahwa ia telah gagal menemukan suatu dasar hukum mengenai perlunya suatu penjatuhan hukuman bagi seseorang yang telah melakukan suatu pelanggaran.

Asas ultimum remedium bukanlah asas konstitusional, namun lebih pada etika legislatif, mulai saat kriminalisasi atau menjadikan suatu perbuatan yang semula bukan tindak pidana menjadi tindak pidana. Doktrin ini harus dipahami dalam kerangka asas-asas yang berkaitan dengan nilai-nilai kebutuhan, efisiensi, keterbatasan, asas kemanfaatan, pertimbangan analisa biaya dan hasil serta asas kemanusiaan, baik yang berkaitan dengan kepentingan pelaku maupun kepentingan korban tindak pidana.

Penjatuhan pidana terhadap anak adalah upaya yang bersifat ultimum remedium, artinya penjatuhan pidana terhadap anak merupakan upaya hukum yang terakhir setelah tidak ada lagi upaya hukum lain yang menguntungkan bagi anak, misalnya anak itu memang sudah sangat meresahkan keluarga dan masyarakat, berkali-kali telah melakukan tindak pidana dan pihak orang tua atau wali sudah tidak ada lagi yang sanggup untuk mendidik dan mengawasinya. ${ }^{31}$

Penerapan asas ultimum remedium tersebut dilakukan melalui peradilan pidana

${ }^{31}$ Bunadi Hidayat, Pemidanaan Anak di Bawah Umur, (Bandung : PT Alumni, 2010), halaman. 84 
anak. Asas ultimum remedium dalam menyelesaikan permasalahan anak yang berkonflik dengan hukum sebenarnya juga telah diatur meski tidak tegas karena secara normatif tidak dituliskan perkataan ultimum remedium itu di dalam pasal yang mengatur tentang anak yang berkonflik dengan hukum, namun secara implisit ada di dalam peraturan perundang-undangan sebagai berikut :

1. Undang-undang hak asasi manusia

Undang-undang nomor 39 tahun 1999 tentang hak asasi manusia dibentuk bertujuan untuk memberikan jaminan perlindungan terhadap hak-hak dasar manusia. Undang-undang ini tidak hanya mengatur tentang perlindungan hak-hak dan kewajiban dasar manusia tetapi juga perlindungan terhadap hak anak. Khusus terhadap jaminan perlindungan anak yang menjalani proses pidana dapat dilihat pada pasal 66. Khusus terhadap jaminan perlindungan anak yang menjalani proses pidana dapat dilihat pada pasal 66 sebagai berikut :

1. Setiap anak berhak untuk tidak dijadikan sasaran penganiayaan, penyiksaan, atau penjatuhan hukuman yang tidak manusiawi

2. Hukuman mati atau hukuman seumur hidup tidak dapat dijatuhkan untuk pelaku tindak pidana yang masih anak

3. Setiap anak berhak untuk tidak dirampas kemerdekaannya secara melawan hukum

4. Penangkapan, penahanan, atau pidana penjara anak hanya boleh dilakukan sesuai dengan hukum yang berlaku dan hanya dapat dilaksanakan sebagai upaya akhir

5. Setiap anak yang dirampas kebebasannnya berhak mendapat perlakuan secara manusiawi dan dengan memperhatikan kebutuhan pengembangan pribadi sesuai dengan usianya dan harus dipisahkan dari orang dewasa, kecuali demi kepentingannya

6. Setiap anak yang dirampas kebebasannya berhak memperoleh bantuan hukum atau bantuan lainnya secara efektif dalam setiap tahapan upaya hukum yang berlaku.
Pasal 66 merupakan suatu upaya perlindungan terhadap anak yang berkonflik dengan hukum yakni dengan menjadikan sistem peradilan pidana anak sebagai langkah/jalan terakhir untuk menyelesaikan perkara anak

2. Undang-undang perlindungan anak

Perlindungan anak bertujuan untuk menjamin terpenuhinya hak-hak anak agar dapat hidup, tumbuh dan berkembang dan berpartisipasi secara optimal sesuai dengan harkat dan martabat kemanusiaan, serta mendapat perlindungan dari kekerasan dan diskriminasi demi terwujudnya anak Indonesia yang berkualitas, berakhlak mulia dan sejahtera. ${ }^{32}$

Perlindungan anak sebagaimana dimaksud diatas datur dalam Bab III tentang hak dan kewajiban anak yakni dimulai dri pasal 4 sampai pasal 19. Hak-hak anak yang berhadapan dengan hukum khususnya diatur di dalam pasal 16 yang menyatakan bahwa,

1. Setiap anak berhak memperoleh perlindungan dari sasaran penganiayaan, penyiksaan atau penjatuhan hukuman yang tidak manusiawi

2. Setiap anak berhak untuk memperoleh kebebasan ssuai dengan hukum

3. Penangkapan, penahanan, atau tindak pidana penjara anak hanya dilakukan apabila sesuai dengan hukum yang berlaku dan hanya dapat dilakukan sebagai upaya terakhir.

Asas ultimum remedium terhadap anak yang berkonflik dengan hukum terdapat di dalam pasal 16 yang menegaskan kembali bahwa sistem peradilan pidana anak yang dimulai dari penangkapan terhadap anak sampai kepada penjatuhan pidana harus dilakukan sebagai upaya terakhir dalam rangka menyelesaikan kasus anak yang berkonflik dengan hukum. Filosofinya adalah untuk mencegah stigmatisasi terhadap anak yang bersangkutan sehingga akan lebih baik jika proses penanganan anak yang brkonflik dengan hukum diselesaikan melalui jalan lain yang menguntungkan baginya dan masa depannya

${ }^{32}$ Pasal 3 Undang-Undang Nomor 23 Tahun 2002 Tentang Perlindungan Anak 
3. Keppres nomor 36 tahun 1990 tentang hak-hak anak

Keputusan Presiden nomor 36 tahun 1990 tentang hak-hak anak merupakan ratifikasi terhadap convention of the right of the child yang merupakan wujud komitmen negara indonesia sebagai salah satu negara pihak dalam konvensi tersebut. Anak, karena alasan ketidakdewasaan fisik dan jiwanya, membutuhkan perlindungan dan pengasuhan khusus, termasuk perlindungan hukum yang tepat baik sebelum dan juga sesudah kelahiran

Perlindungan hukum terhadap anak yang berkonflik dengan hukum terdapat di dalam Pasal 37 yang memberikan amanah kepada negara pihak untuk menyelenggarakan mekanisme penyelesaian kasus anak yang berkonflik dengan hukum yang efektif, ramah dan menjamin perlindungan anak dengan menjadikan sistem peradilan pidana anak sebagai jalan terakhir. Pasal 37 menyatakan bahwa :

1. Tidak seorang anak pun dapat dijadikan sasaran penganiayaan, atau perlakuan kejam yang lain, tidak manusiawi atau hukuman yang menghinakan baik hukuman mati atau pemenjaraan seumur hidup tanpa kemungkinan pembebasan, tidak dapat dikenakan untuk pelanggaranpelanggaran yang dilakukan oleh orang-orang di bawah umur delapan belas tahun

2. Tidak seorang anak pun dapat dirampas kebebasannya secara melanggar hukum atau dengan sewenag-wenang. Penangkapan, penahanan atau pemenjaraan seorang anak harus sesuai dengan undaangundang, dan harus digunakan hanya sebagai upaya jalan lain terakhir dan untuk jangka waktu pendek

3. Setiap anak yang dirampas kemerdekaannya harus diperlakukan manusiawi dan menghormati martabat manusia yang melekat dan dalam suatu cara dan mengingat akan kebutuhankebutuhan orang pada umumnya. Terutama, setiap anak yang dirampas kemerdekaannya harus dipisahkan dari orang dewasa kecuali penempatannya itu dianggap demi kepentingan si anak dan harus mempunyai hak untuk mempertahankan kontak dengan keluarga melalui surat menyurat dan kunjungan, kecuali dalam keadaankeadaan luar biasa

4. Setiap anak yang dirampas kebebasannya berhak atas akses bantuan hukum dan bantuan lain yang tepat, dan juga hak untuk menyangkal keabsahan perampasan kebebasannya di hadapan suatu pengadilan ataupun penguasa lain yang berwenang, mandiri dan adil dan atas putusan segera mengenai tindakan apa pun semacam itu.

Asas ultimum remedium terhadap anak yang berkonflik dengan hukum juga telah diadopsi di dalam undang-undang sistem peradilan pidana anak yang baru yaitu undang-undang nomor 11 tahun 2012 khususnya pasal 2 yang intinya menyatakan bahwa pada dasarnya anak tidak dapat dirampas kemerdekaannya kecuali terpaksa guna kepentingan penyelesaian perkara. Aplikasi asas ultimum remedium terhadap anak yang berkonflik dengan hukum ditujukan pada jenis tindak pidana yang dilakukan dengan ancaman pidana penjara di bawah 7 tahun dan tindak pidana yang dilakukan bukan merupakan pengulangan tindak pidana. Dengan demikian, implementai asas ultimum remedium ini dikecualikan penerapannya di dalam undang-undang terhadap anak yang melakukan tindak pidana berat atau dengan kata lain tidak semua tindak pidana yang dilakukan oleh anak dapat diselesaikan di luar sistem peradilan pidana formal sebagai wujud ultimum remedium.

Peraturan perundang-undangan di atas telah menjelaskan dan mengamanahkan bahwa dalam menyelesaikan permasalahan anak penggunaan hukum pidana yang penerapannya dilakukan melalui sistem peradilan pidana anak dihindari sebagai bentuk perlindungan terhadap anak mengingat usianya yang masih muda dan masa depan yang masih jauh membentang.

\section{Asas ultimum remedium terhadap anak yang berkonflik dengan hukum dalam rangka perlindungan}


anak dalam putusan mahkamah agung ri no.125/pid/a/2012/pn.gs

WHD adalah seorang remaja laki-laki berusia 16 tahun. Suatu hari ia bertandang main ke salah satu temannya, namun temannya yang bersangkutan belum pulang sehingga ia bertemu dengan ayah temannya yang bernama BSR. Sembari menunggu ia mengobrol dengan BSR yang kemudian mengajaknya untuk mengambil buah kelapa sawit milik PTPN VII Padang Ratu dengan menggunakan tombak miliknya. Awalnya, WHD menolak ajakan BSR tersebut karena takut dimarahi oleh kakaknya namun BSR berhasil membujuknya sehingga keesokan harinya WHD datang ke rumah BSR untuk menjalankan rencana mereka mengambil buah kelapa sawit tersebut.

Sesampainya di PTPN VII mereka langsung mencari buah kelapa sawit untuk diambil. WHD bertugas mengawasi situasi sekitar untuk memastikan bahwa perbuatan BSR memetik buah kelapa sawit dengan menggunakan golok miliknya tidak diketahui oleh orang lain serta memaasukkan buah kelapa sawit yang telah diambil ke dalam karung goni yang telah disiapkan sebelumnya. Namun, pada saat sedang memetik buah kelapa sawit tersebut, WHD dan BSR tertangkap tangan oleh pihak keamanan PTPN VII Padang Ratu untuk selanjutnya diserahkan kepada pihak yang berwajib untuk mempertanggungjawabkan perbuatannya. Atas kejadian tersebut PTPN VII Padang Ratu menderita kerugian sebesar Rp.200.000,.

Berdasarkan hal tersebut diatas, maka jaksa penuntut umum mengajukan tuntutan maksimal 7 tahun penjara terhadap WHD. Tuntutan jaksa penuntut umum ini dibacakan dan diserahkan di persidangan pada saat Pengadilan Gunung Sugih memeriksa kasus ini.

Bunyi putusan mahkamah agung yang menyatakan terdakwa melakukan tindak pidana percobaan pencurian dengan pemberatan sudah tepat dan benar. Hal ini sesuai dengan pasal 53 KUHP jo Pasal 363 Ayat (1) ke 4 KUHP. Bunyi putusan mahkamah agung yang menjatuhkan tindakan kepada terdakwa dengan mengembalikannya kepada orang tua juga sudah tepat. Hal ini sesuai dengan Pasal 24 UU nomor 3 Tahun 1997 tentang Pengadilan
Anak. Meskipun WHD dikembalikan kepada orang tuanya, WHD tetap berada di bawah pengawasan dan bimbingan kemasyarakatan antara lain mengikuti kegiatan kepramukaan dan lainnya. Jika dilihat dari sudut teori-teori pemidanaan, maka sanksi tindakan merupakan sanksi yang tidak membalas. Ia semata-mata ditujukan pada prevensi khusus, yaitu melindungi masyarakat dari ancaman yang dapat merugikan kepentingan masyarakat itu. Sanksi tindakan berorientasi pada ide perlindungan masyarakat dan tujuannya lebih bersifat mendidik.

Mengenai pertimbangan hukum dalam putusan mahkamah agung, salah satunya dengan mencantumkan asas ultimum remedium dalam menyelesaikan perkara anak yang berkonflik dengan hukum adalah keliru. Ultimum remedium terhadap anak yang berkonflik dengan hukum maksudnya adalah dengan menjadikan keseluruhan proses peradilan pidana anak sebagai jalan terakhir. Hal tersebut sesuai dengan Pasal 16 UU nomor 23 tahun 2002 tentang perlindungan anak.

Asas pemidanaan yang dijatuhkan terhadap anak yang berkonflik dengan hukum dalam putusan mahkamah agung cukup berpedoman kepada asas kepentingan terbaik bagi anak, dimana dalam semua tindakan yang menyangkut anak yang dilakukan oleh pemerintah, masyarakat, badan legislatif, dan badan yudikatif maka kepentingan terbaik bagi anak harus menjadi pertimbangan utama. Implementasi asas kepentingan terbaik bagi anak sudah tercermin di dalam putusan hakim di atas yang menjatuhkan tindakan kepada WHD, dimana tindakan mengembalikan terdakwa kepada orang tuanya merupakan kepentingan terbaik bagi terdakwa karena hakim menganggap perbuatan terdakwa bukan merupakan tindak pidana serius terlebih dilakukan dengan motivasi ingin mendapatkan uang jajan serta terdakwa sendiri belum pernah melakukan tindak pidana sebelumnya.

Asas ultimum remedium merupakan asas yang menjiwai lahirnya konsep diversi dan restorative justice di dalam menyelesaikan permasalahan anak yang berkonflik dengan hukum sehingga mahkamah agung tidak dapat 
memasukkannya sebagai salah satu dasar pertimbangan dalam menjatuhkan putusan terhadap anak yang berkonflik dengan hukum. Asas ultimum remedium bukanlah asas yang menjiwai pemberian keputusan dalam hal ini penjatuhan tindakan terhadap terdakwa melainkan merupakan asas hukum yang menempatkan keseluruhan proses pengadilan pidana anak sebaagai langkah akhir yang harus ditempuh.

\section{Penutup \\ A. Kesimpulan}

Berdasarkan hasil penelitian dan pembahasan sebagaimana yang telah diuraikan pada bab sebelumnya, maka dapat disimpulkan beberapa hal, yaitu sebagai berikut :

1. Keberadaan/adopsi asas ultimum remedium di dalam instrumen hukum internasional yang mengatur tentang anak adalah secara implisit terdapat di dalam Pasal 37 Convention of the right of the child, Pasal 46 The riyadh Guidelines, Pasal 16 The tokyo rules, fundamental perspective havana rules serta pasal 13 beijing rules

2. Keberadaan/adopsi asas ultimum remedium di dalam instrumen hukum nasional yang mengatur tentang anak adalah secara implisit terdapat di dalam Pasal 66 UU hak asasi manusia no 39 tahun 1999, Pasal 16 UU perlindungan anak no 23 tahun 2002, Pasal 37 Keppres No 36 tahun 1990 tentang ratifikasi terhadap konvensi hak anak.

3. Keberadaan/adopsi asas ultimum remedium di dalam putusan Mahkamah Agung RI no.125/pid/a/2012/pn.gs adalah keliru dan tidak tepat. Asas ultimum remedium terhadap anak yang berkonflik dengan hukum maksudnya adalah dengan menjadikan keseluruhan proses peradilan anak sebagai jalan terakhir.

\section{B. Saran}

1. Perlu untuk mengatur asas ultimum remedium ini secara eksplisit di dalam Resolusi-Resolusi Majelis Umum PBB yang mengatur tentang anak

2. Perlu untuk mengatur asas ultimum remedium secara eksplisit di dalam peraturan perundang-undangan nasional serta menentukan batas-batas perbuatan pidana apa saja yang bisa diselesaikan dengan menerapkan asas ini kepada anak yang berkonflik dengan hukum.

3. Perlu bagi hakim anak untuk benarbenar memahami asas-asas hukum serta peraturan perundang-undangan yang berkaitan dengan penyelesaian perkara anak sehingga menghasilkan putusan pengadilan yang bijaksana bagi anak yang berkonflik dengan hukum.

\section{DAFTAR PUSTAKA}

Abidin , Zainal Farid,2007, Hukum Pidana I, Sinar Grafika, Jakarta

Adi, Rianto, 2000, Metode Penelitian Sosial dan Hukum, Granit, Jakarta.

Ekaputra, Mohammad, 2010, Dasar-Dasar

Hukum Pidana, USU Press, Medan.

Gultom, Maidin, 2008, Perlindungan Hukum

Terhadap Anak Dalam Sistem Peradilan

Pidana Anak di Indonesia, PT Refika Aditama, Bandung

Hadi, Sutrisno, 2000, Metode Research Jilid I, Penerbit Andi, Yogyakarta.

Hidayat, Bunadi, 2010, Pemidanaan Anak di

Bawah Umur, PT Alumni, Bandung

Hartono, Sunaryati, 1994, Penelitian Hukum Indonesia pada Akhir ke-20, Alumni, Bandung.

Hutagalung, Sophar maru, 2014, Praktik peradilan perdata dan Alternatif penyelesaian sengketa, Sinar grafika, Jakarta

Ibrahim, Johny, 2008, teori dan metodologi penelitian hukum normatif, Banyumedia publishing, Malang.

I Wayan, I Parthiana, Pengantar Hukum

Internasional, 2003, Mandar Maju, Bandung

Mas, Marwan, 2004, Pengantar Ilmu Hukum,

Ghalia, Jakarta

Marlina (1), 2009, Peradilan Pidana Anak di

Indonesia Pengembangan Konsep Diversi dan

Restorative Justice, PT Refika Aditama,

Bandung

Marlina (2), 2010, Pengantar Konsep diversi dan Restorative Justice Dalam Hukum Pidana, USU Press, Medan

Nazir, Mohd, 1998, Metode Penelitian, Ghalia Indonesia, Jakarta. 
Soekanto, Soerjono, 2006, pengantar penelitian hukum, UI press, Jakarta.

Soekanto, Soerjono, 1995, Penelitian Hukum Normatif suatu tinjauan singkat, Raja Grafindo Persada, Jakarta.

Soekanto, Soerjono dan Sri Mamudji, 1979, Peran Penggunaan Perpustakaan di dalam penelitian Hukum, PDHUI, Jakarta.

Sumaryo Suryokusumo, Sumaryo, 2007, Studi Kasus Hukum Internasional. Tatanusa, Jakarta

Soetodjo, Wagiati, 2008,, Hukum Pidana Anak, PT Refika Aditama, Bandung Supeno, Hadi, 2010, Kriminalisasi Anak Tawaran Gagasan Radikal Peradilan Anak Tanpa Pemidanaan, PT Gramedia, Jakarta Sudarto, 2006, Kapita Selekta Hukum Pidana, Alumni, Bandung

Muladi, 2003, Makalah Ambiguitas dalam Penerapan Doktrin Hukum Pidana Antara Doktrin Ultimum remedium dan Doktrin Primum Remedium, Makassar 